\title{
RESEARCHING SELF-ASSESSMENT OF STUDENT TEACHERS' PEDAGOGICAL ACTIVITY IN THEORY AND PRACTICE
}

\author{
Evija Latkovska \\ Lūcija Rutka
}

University of Latvia, Faculty of Education, Psychology and Art

\begin{abstract}
In professional growth of teachers, self-assessment of the pedagogical activity is a precondition for their effective practice therefore student teachers are encouraged to carry out self-assessment of the pedagogical activity already at the beginning of their studies. In order to make self-assessment of student teachers' pedagogical activity more productive, it is important to find out a theoretical concept of self-assessment of student teachers' pedagogical activity and to understand what impacts self-assessment of their pedagogical activity in practice. In the due course of the analysis of the scientific literature definition and functions of self-assessment of student teachers' pedagogical activity, definition, functions, criteria and indicators of the self-assessment skill of student teachers' pedagogical activity are formulated and as a result of the empirical research preconditions for successful self-assessment of student teachers' pedagogical activity are revealed.
\end{abstract}

Keywords. Pedagogical activity, self-assessment, self-assessment of pedagogical activity, student teachers.

\section{Introduction}

In the contemporary society requirements for teachers keep growing and they have to be flexible in carrying out their duties (Bluma, 2012; Improving the Quality of Teacher Education, 2007; Green, 2006; Ball, 2000; Sparks-Langer \& Colton, 1991), and determined in their professional growth. Therefore teacher education programmes offer student teachers study on a metacognitive level, thus helping them formulate pedagogical principles of their activity (Loughran, 2006). Metacognitive learning means continuous self-assessment of one's activity by asking questions and looking for answers about the main idea of learning, impact of practice and experience on further learning and pedagogical activity, how to make learning and pedagogical activity more productive, etc. (Loughran, 2006). Therefore student teachers of teacher education programmes are encouraged to carry out self-assessment of the pedagogical activity already at the beginning of their studies as it means active student teachers' participation in their learning about teaching, and it reflects both: an idea of humanistic education and psychology about a student-centred study process which aims at fostering a person's self-actualisation in a supportive environment by promoting one's openness to everything new and development throughout the whole life (Koķe, 2002; Lieǵeniece, 2002; Knowles, 1975; Rogers, 1969) and an idea of social-constructivism about a person's development that takes a form of constructing one's reality in the process of socialisation (Beck \& Kosnik, 2006; Mundhenk, 2004; Žogla, 2001; Vygotsky, 1978). By being actively involved in 
the study process, feeling responsible for it and being the ones who decide upon the direction of their learning, student teachers have an opportunity to raise their self-esteem, improve their attitude towards learning, to learn more profoundly, and it all results in a better performance (Mundhenk, 2004).

Even though human beings demonstrate a natural ability to perceive themselves as assessment objects (Povinelli \& Prince, 1998) and they can assess their skills according to certain criteria (Duval \& Wicklund, 1972), thus being able to define necessary paths for further development (Sedikides \& Strube, 1997), student teachers sometimes find it difficult to look on self-assessment as a natural component of their learning (Jokinen \& Saranen, 1998) and not always they know how to assess their activity and understand the role of self-assessment in their professional development.

The aim of the article is to study a theoretical concept of self-assessment of student-teachers' pedagogical activity and in the empirical research to find out the level of student teachers' self-assessment skill of their pedagogical activity. Research questions:

1. What is a theoretical concept of self-assessment of student teachers' pedagogical activity?

2. How and on what level does student teachers' self-assessment skill of the pedagogical activity show in practice?

Research methods:

1. Analysis of the scientific literature.

2. Data collection method: analysis of documents - written student teachers' self-assessments of their pedagogical activity.

3. Data processing method: qualitative content analysis and interpretation (Kroplijs \& Raščevska, 2010; Cohen et al, 2007; Geske \& Grīnfelds, 2006; Lasmanis, 2002).

Data processing instrument: a programme of analysing qualitative data AQUAD 7 (Huber \& Gürtler, 2013).

Research sample is a non-probability convenience sample (Creswell, 2009; Cohen et. al., 2007) $-124^{\text {th }}$ year student teachers of the study programme $\mathrm{x}$ at the faculty of Education, Psychology and Art (EPA), the University of Latvia (UL).

The actual research is a part of a more profound research that is carried out as action research (Creswell, 2009; Altrichter et.al., 2008; Cohen et. al., 2007; Borko et.al., 2007; Koshy, 2005) with an aim to benefit to a certain practice situation in future by reflecting reality and introducing changes into it (Cohen et. al., 2007), which within the frames of this research is self-assessment of student teachers' pedagogical activity.

Research procedure:

The empirical research was carried out in February-Marh of 2012 when besides the compulsory requirements for their teaching practicum $124^{\text {th }}$ year student teachers of the study programme $\mathrm{x}$ of the faculty of EPA, of the UL, agreed to 
participate in a purposeful and structured process of self-assessment of student teachers' pedagogical activity organised by the authors of the article. For all the participants of the research this is their first higher education experience. During these 2 months 12 student teachers did 8 different self-assessment tasks of their pedagogical activity, and 1 of them was a written self-assessment of the pedagogical activity.

\section{Theoretical Concept of Self-Assessment of Student Teachers' Pedagogical Activity}

In order to do their job effectively teachers nowadays should be aware of the growing importance of self-assessment of the pedagogical activity and enhancement of their professional growth (Andersone \& Rutka, 2012; Improving the Quality of Teacher Education, 2007; A National Framework for Professional Standards for Teaching, 2003; Coolahan, 2002; Crandall, 2000; Darling-Hammond \& Sykes, 1999). During self-assessment of the pedagogical activity teachers get accustomed to new assessment principles (Jokinen \& Saranen, 1998) that emphasise the role of self-assessment of the pedagogical activity as one of the main elements that guarantees the quality of the teaching/learning process at schools.

Student teachers form their understanding of self-assessment of the pedagogical activity in their studies when they have an opportunity to be the primary source of information for themselves about knowledge on teaching and learning (Crandall, 2000) and they get a purposeful and meaningful experience they can learn from (Berry \& Loughran, 2000). In its turn inclusion of self-assessment of the pedagogical activity in study programmes is one of the most effective ways to foster students' learning (Struyven, et. al., 2005; Jokinen \& Saranen, 1998; Bowen \& Marks, 1994). It means that student teachers should be encouraged to carry out systematic self-assessment of the pedagogical activity already at the beginning of their studies in that way getting used to assessing their decisions and choices of the pedagogical activity also in future. If in teacher education programmes there is no possibility for student teachers to learn how to selfassess the pedagogical activity and become aware of its significance in their further development, their self-assessment of the pedagogical activity is superficial and they find it difficult to reflect on their performance (Jokinen \& Saranen, 1998). Such a situation asks student teacher educators show trust in their students and to assign the active roles to students, they themselves rather taking on responsibilities of consultants, advisers and assisstants not just simply passing on knowledge (Bluma, 2012).This kind of a paradigm shift regarding the role of students and aspects of their assessment at higher education establishments took place at the end of the $20^{\text {th }}$ century based on the idea that students in the process of their studies should be looked on as active participants who also are responsible for the quality of their studies, who reflect, cooperate 
and communicate with educators; exactly at this point self-assessment, peerassessment and co-assessment became heralds of the 'new assessment era' in which the main task of assessment is to foster students' learning and follow their progress not being focused on assessing reproduction of knowledge (Cartney, 2010; Taras, 2002; Dochy et. al., 1999).

As a result of analysis of the scientific literature on self-assessment of student teachers' pedagogical activity and the student teachers' self-assessment skill of their pedagogical activity (Andrade \& Du 2007; Hahele, 2006; Mundhenk, 2004; Boud, 2003; McAlpine, 2002; Falchikov \& Goldfinch, 2000; Sluijsmans et.al., 1999; Jokinen \& Saranen,1998; Klenowski, 1995; Airasian \& Gullickson, 1994; Boud \& Falchikov, 1989) a definition and functions of self-assessment of student teachers' pedagogical activity are formulated as well as the definition and functions of the student teachers' self-assessment skill of their pedagogical activity are formulated.

Self-assessment of student teachers' pedagogical activity is defined as a selfinitiated, conscious, purposeful and structured reflection on their pedagogical activity. It results in decisions about achievements in their pedagogical activity and they think of the aim, directions and objectives of their professional development. Its functions are the following:

1. Diagnostic - to determine student teachers' achievements in their pedagogical activity.

2. Informative - to determine the aim, directions and objectives of student teachers' further professional development.

3. Encouraging - to promote student teachers' professional responsibility by emphasising their independence and raising interest in self-assessment of the pedagogical activity.

4. Developmental - to motivate student teachers to self-assess the pedagogical activity on daily basis with an aim to contribute to every pupil's individual development thus raising the overall quality of the teaching/learning process.

The student teachers' self-assesment skill of their pedagogical activity is a student teachers' ability to assess the content of their pedagogical activity against certain criteria and to use the obtained outcomes in taking decisions on achievements of their pedagogical activity and opportunities for its further development. Its functions are the following:

1. Cognitive - acquiring knowledge and formulating understanding of the concept of self-assessment of the pedagogical activity and assessment criteria of the pedagogical activity.

2. Practical - the use of knowledge in daily practice and new situations.

3. Moral - developing attitude towards self-assessment of the pedagogical activity so that self-assessment of the pedagogical activity would give input in further student teachers' professional development by becoming aware 
that all in all it helps to enhance every pupil's growth and the overall quality of the teaching/learning process.

4. Emotional - sensing and spotting emotions that arise in student teachers' pedagogical activity with an aim to develop student teachers' understanding of their pedagogical principles, enhance emotional selfregulation and to get emotional fulfilment in the pedagogical activity.

Based on the theoretical concept of both terms and their understanding within the frames of the actual research, the empirical research was conducted in order to find out how and on what level student teachers' self-assessment skill of the pedagogical activity shows in practice.

\section{Researching Student Teachers' Self-Assesement Skill of the Pedagogical Activity}

Student teachers' self-assessment skill of the pedagogical activity is analysed based on its research criteria, their indicators and levels (Table 1).

The criteria and indicators used in the empirical research to study the student teachers' self-assessment skill of the pedagogical activity are defined in accordance with the theoretical concept of the terms self-assessment of student teachers's pedagogical activity and student teachers' self-assessment skill of the pedagogical activity formulated as a result of the analysis of the scientific literature. Levels and assessment descriptions of the criteria 'knowledge on selfassessment of the pedagogical activity', 'understaning self-assessment of the pedagogical activity', and 'planning further pedagogical activity' are made based on the methodological material on assessment of achievements of secondary school pupils written by specialists of the National Centre of Education (VISC, 2009) as this material offers core principles of assessing knowledge and understanding and these principles are used in all educational establishments in Latvia. Levels and assessment descriptions of the criterion 'reflection on one's pedagogical activity' are made based on the approach to determining levels of student teachers' reflective thinking and its assessment developed by H.-J. Lee (Lee, 2005). Levels and assessment descriptions of the criterion 'attitude towards self-assessment of the pedagogical activity' are made based on the characteristics of different kinds of attitudes worked out by A.Špona (Špona, 2006). Levels and their assessment descriptors of all the criteria in this empirical research are adapted to the context of the research - the teacher education study programme at the higher education establishment.

During the process of qualitative content analysis correspondingly to the criteria, their indicators and levels 48 codes were formed. While analysising the student teachers' written self-assessments of their pedagogical activity, 19 codes appeared, and student teachers' self-assessment skill of the pedagogical ativity was analysed based on the frequency these codes reappeared. Student teachers' written self-assessments of their pedagogical activity were also interpreted. 
Research criteria, their indicators and levels of student teachers' self-assessment skill of the pedagogical activity.

\begin{tabular}{|c|c|c|}
\hline criteria & indicators & levels \\
\hline \multirow{3}{*}{$\begin{array}{l}\text { Knowledge on } \\
\text { self-assessment of } \\
\text { the pedagogical } \\
\text { activity. }\end{array}$} & $\begin{array}{l}\text { Knowledge on functions of self- } \\
\text { assessment of the pedagogical activity. }\end{array}$ & \multirow{3}{*}{$\begin{array}{l}\text { Level of understanding. } \\
\text { Level of application. } \\
\text { Level of productive } \\
\text { activity. }\end{array}$} \\
\hline & $\begin{array}{l}\text { Knowledge on a structure of self- } \\
\text { assessment of the pedagogical activity. }\end{array}$ & \\
\hline & $\begin{array}{l}\text { Knowledge on an organisation of self- } \\
\text { assessment of the pedagogical activity. }\end{array}$ & \\
\hline \multirow{3}{*}{$\begin{array}{l}\text { Understaning self- } \\
\text { assessment of the } \\
\text { pedagogical } \\
\text { activity. }\end{array}$} & $\begin{array}{l}\text { Understanding the criteria of self- } \\
\text { assessment of the pedagogical activity. }\end{array}$ & \multirow{3}{*}{$\begin{array}{l}\text { Level of understanding. } \\
\text { Level of application. } \\
\text { Level of productive } \\
\text { activity. }\end{array}$} \\
\hline & $\begin{array}{l}\text { Understanding the use of the outcomes of } \\
\text { self-assessment of the pedagogical } \\
\text { activity in ensuring the quality of the } \\
\text { pupils' learning process. }\end{array}$ & \\
\hline & $\begin{array}{l}\text { Understanding the benefit of self- } \\
\text { assessment of the pedagogical activity for } \\
\text { one's professional development. }\end{array}$ & \\
\hline \multirow[t]{4}{*}{$\begin{array}{l}\text { Reflection on } \\
\text { one's pedagogical } \\
\text { activity. }\end{array}$} & $\begin{array}{l}\text { Reflection on the impact of the } \\
\text { environment on one's pedagogical } \\
\text { activity. }\end{array}$ & \multirow[t]{4}{*}{$\begin{array}{l}\text { Level of recalling. } \\
\text { Level of rationalization. } \\
\text { Level of reflectivity. }\end{array}$} \\
\hline & $\begin{array}{l}\text { Reflection on one's behaviour in the } \\
\text { pedagogical activity. }\end{array}$ & \\
\hline & $\begin{array}{l}\text { Reflection on one's skills/competence in } \\
\text { the pedagogical activity. }\end{array}$ & \\
\hline & $\begin{array}{l}\text { Reflection on one's views within the } \\
\text { context of the pedagogical activity. }\end{array}$ & \\
\hline \multirow{3}{*}{$\begin{array}{l}\text { Planning further } \\
\text { pedagogical } \\
\text { activity. }\end{array}$} & $\begin{array}{l}\text { Setting the aim and directions of one's } \\
\text { further professional development. }\end{array}$ & \multirow{3}{*}{$\begin{array}{l}\text { Level of understanding. } \\
\text { Level of application. } \\
\text { Level of productive } \\
\text { activity. }\end{array}$} \\
\hline & $\begin{array}{l}\text { Setting the tasks of one's further } \\
\text { professional development. }\end{array}$ & \\
\hline & $\begin{array}{l}\text { Anticipating outcomes of one's further } \\
\text { pedagogical activity. }\end{array}$ & \\
\hline \multirow{3}{*}{$\begin{array}{l}\text { Attitude towards } \\
\text { self-assessment of } \\
\text { the pedagogical } \\
\text { activity. }\end{array}$} & $\begin{array}{l}\text { Demonstrating initiative in self-assessing } \\
\text { the pedagogical activity. }\end{array}$ & \multirow{3}{*}{$\begin{array}{l}\text { Situational attitudes. } \\
\text { Habitual attitudes. } \\
\text { Self-regulation attitudes. }\end{array}$} \\
\hline & $\begin{array}{l}\text { Readiness to cooperate in discussing } \\
\text { one's pedagogical activity. }\end{array}$ & \\
\hline & $\begin{array}{l}\text { Responsibility for the quality of one's } \\
\text { pedagogical activity. }\end{array}$ & \\
\hline
\end{tabular}

Within this article student teachers' self-assessment skill of the pedagogical activity is analysed for the whole group of respondents together not taking into account reappearance of codes in individual student teachers' written selfassessments of their pedagogical activity.

Out of all five criteria in student teachers' written self-assessments most often the criterion 'reflection on one's pedagogical activity' appeared (255 times), and 
among its indicators the indicator 'reflection on one's skills/competence in the pedagogical activity' was mentioned most often (133 times). Student teachers' expressions regarding this indicator are mainly on the lowest - recalling - level, which is characterised with highlighting separate facts and actions not trying to look for alternatives for explaining one's activity. It can be illustrated with the following student teachers' expressions:'I can organise the lesson differently: frontal work with the whole class, pair work and group work, helping pupils individually, if it is necessary', 'I can also communicate with pupils'. However there are also expressions that give evidence about rationalisation level (17 times) and the highest - reflectivity level (9 times) of student teachers'reflective thinking, which can be characterised with the following expression: 'I think that I have to ask a bit more from pupils, especially secondary school pupils. If at basic school pupils do not use it yet, then at secondary school pupils already start using the fact that a teacher is not so strict with them and they start to manipulate with different things (for example, letting free earlier for the break, not giving homework, not writing tests, etc). Even though I myself want to give them more freedom as I have graduated from secondary school just recently and I do understand that feeling when you do not want to do anything, but school is school and they go to school not to have rest but to get knowledge. Therefore I reckon that I have to change my attitude to maintain better discipline at lessons'.

A second most often mentioned code pertains to the indicator 'reflection on one's behaviour in the pedagogical activity' (61 times). However also here student teachers' expressions are on the level of recalling (57times) and just 4 expressions belong to the rationalisation level which means that student teachers look for causes-consequences relationships in their pedagogical activity. It can be concluded that generally student teachers find it relatively easy to reflect on things they can characterise with their physical behaviour - their skills/competence and behaviour in the pedagogical activity - but they do it without going into profound analysis and not looking for theoretical underpinnings of their deeds to be able to use them also in similar situations in future, instead they focus on separate events. It is possible that for student teachers it was easier to reflect on their skills and behaviour also because besides the written self-assessment of the pedagogical activity they had to fill in tables with certain performance criteria against which they had to self-assess their pedagogical activity, and thanks to these criteria it was easier for student teachers to notice and assess exactly their skills and behaviour.

As regards level of reflectivity student teachers showed it also in the indicator 'reflection on one's views within the context of the pedagogical activity' (6 times out of 46 times for this code altogether), for example: 'When designing tests I certainly include tasks we have discussed in lessons, tasks we have already done, and I include things I have attracted their attention to with respect to the test. I think that it is the thing that encourages pupils and they know what 
to get ready for, not making them repeat all the words that are in the chapter just because they might be included in the test. That would cause unnecessary stress for pupils and they would not repeat anything as they would not be able to learn everything anyway. There will be no gains, the marks will be lower and motivation will disappear.', which makes the authors of the article think that student teachers are able to argument their views, skills and behaviour with theoretical underpinnings they can use also in other appropriate situations in their pedagogical activity, but for that student teachers, most probably, have to be more motivated to self-assess their pedagogical activity.

'Attitude towards self-assessment of the pedagogical activity' - is a second most often mentioned criterion (63 times) in the student teachers' written selfassessments of the pedagogical activity, out of which indicators student teachers most often write about 'responsibility for the quality of one's pedagogical activity' (34 times) evenly revealing habitual attitudes (19 times) and the highest level - self-regulation - attitudes (15 times), for example: 'Regarding the use of the language I try to think about giving instructions. Not always it is linked with the way how I explain tasks, but pupils often say that they do not understand what they have to do (sometimes however it is because they simply do not listen to me). After I have given instructions I ask one more time if they understand what they have to do and I usually ask to repeat instructions one more time to some active pupil, with an aim to make sure that they have understood what I have asked them to do.'. Self-regulation attitudes dominate also in two other indicators of this criterion - about initiative (11 times) when student teachers express self-initiative for self-assessment of the pedagogical activity and about cooperation ( 9 times) when student teachers demonstrate readiness to cooperate in self-assessing their pedagogical activity, for example, with student teacher educators or school mentors. These student teachers' expressions let conclude that they are aware of the role self-assessment of the pedagogical activity plays for the quality of their pedagogical activity nevertheless they need support and external motivation to be more reflective in self-assessing their pedagogical activity, and this external motivation can be provided by student teacher educators and school mentors.

The third most often mentioned criterion in student teachers' written selfassessments is 'planning further pedagogical activity' (33 times), which reveals that concerning their professional development student teachers set only its aim and directions neither going into details about specific tasks nor predicting outcomes of their further pedagogical activity. Sadly, but setting the aim and directions of further professional development happens more on the levels of understanding (13 times) and application (20 times) that respectively are characterised by difficulties in setting the aim and directions of one's professional development and demonstrating some understanding when talking about the aim and directions of the professional development. For example: ' $I$ should think about the fact if I speak grammatically correctly because my 
sentences in past often are not correct. (When I use did the verb stays in past, but I try to work on that and think what I say.) I sometimes get mixed in things I am saying and then I do not know how to finish the sentence so that it had some sense, but I hope that it will come with time.' It means that also in this aspect student teachers need help and motivation that can be provided by student teacher educators and school mentors.

In the student teachers' written self-assessments of their pedagogical activity there were no codes regarding the criterion 'knowledge on self-assessment of the pedagogical activity' and only one code ( 2 times) regarding the criterion 'understanding self-assessment of the pedagogical activity' which means that in order student teachers could show their self-assessment skill of the pedagogical activity with respect to these criteria and for the authors of the article to analyse the level of student teachers' self-assessment skill of the pedagogical activity for these criteria a different task is required.

\section{Conclusions and Discussion}

The task of self-assessment of student teachers' pedagogical activity is to help student teachers determine the quality of their pedagogical activity and set the aim, directions and tasks of the necessary further development simultaneously encouraging student teachers' responsibility for the quality of their pedagogical activity and raising their interest in carrying out self-assessment of the pedagogical activity on daily basis. The theoretical concept of the student teachers' self-assessment skill of their pedagogical activity is the competent use of the self-assessment criteria of the pedagogical activity in practice so that it would result in acquiring new knowledge, developing attitude towards selfassessment of the pedagogical activity and emotional fulfilment in the pedagogical activity.

Similar to the research findings of H.Jokinen and E.Saranen (Jokinen \& Saranen,1998) also the data of the actual empirical research confirm that student teachers find it easier to self-assess their pedagogical activity and the student teachers' self-assessment skill of the pedagogical activity is on a higher level if self-assessment of the pedagogical activity runs in a conscious and planned manner and the self-assessment process has a structure student teachers can follow when reflecting on their pedagogical activity (Green, 2006). Selfassessment of student teachers' pedagogical activity is encouraged if student teachers have access to objective performance self-assessment criteria (Silvia \& Phillips, 2004; Drew, 2001), as these criteria help student teachers to analyse the quality of their skills and behaviour. However, an issue here then is the content and volume of the self-assessment criteria of the pedagogical practice - there should not be too many of the criteria and they should be understandable to student teachers (Improving the Quality of Teacher Education, 2007; Loughran, 2006; Moore, 2004). 
Based on the analysis of the data of the empirical research it can be concluded that a significant factor in the successful process of self-assessment of student teachers' pedagogical activity and the development of the student teachers' selfassessment skill of the pedagogical practice is teacher educators and school mentors' cooperation with student teachers which helps student teachers shape their understanding of the quality of their pedagogical activity and find solutions for difficulties they face in their pedagogical activity. Feedback from teacher educators and school mentors during self-assessment of student teachers' pedagogical activity facilitates the development of the student teachers' selfassessment skill of the pedagogical activity.

Findings of the theoretical and empirical research constitute basis for thoughts about possibilities to include in teacher education programmes purposeful, structured and teacher educator and school mentor guided student teachers' selfassessment of their pedagogical activity.

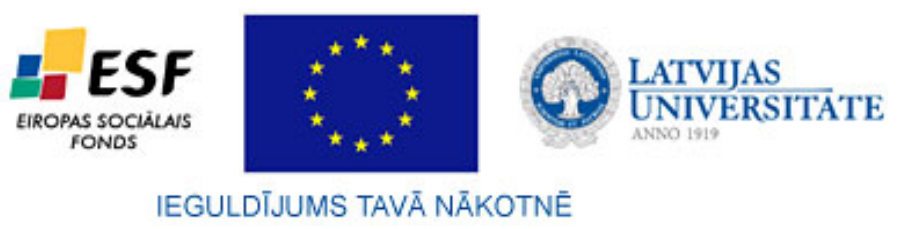

This work has been supported by the European Social Fund within the project «Support for Doctoral Studies at University of Latvia».

\section{References}

1. Airasian, P. W., Gullickson, A. (1994). Examination of Teacher Self-Assessment. Journal of Personnel Evaluation in Education. Vol. 8, pp. 195-203.

2. Altrichter, H., Feldman, A., Posch, P., Somekh, B. (2008). Teachers Investigate their Work. An Introduction to action research across the professions. London and New York: Routledge Taylor\&Francis Group.

3. (2003). A National Framework for Professional Standards for Teaching http://www.curriculum.edu.au/verve/_resources/national_framework_file.pdf (20.01.2014)

4. Andersone, R., Rutka, L. (2012). Development of Competences for Professional Activities: the Latvian Case. In Nowosad, I. and Kobylecka, E. (Eds.)Teachers Training in the European Space of Higher Education. Poland: Wydawnictwo Adam Marszalek, No. 1(3), pp.228-245.

5. Andrade, H., Du, Y. (2007). Student responses to criteria-referenced self-assessment. Assessment and Evaluation in Higher Education. Vol. 32, No. 2, pp. 159-181.

6. Ball, D. L. (2000). Bridging Practices - Intertwining Content and pedagogy in Teaching and leraning to Teach. Journal of Teacher Education. Vol.51, No.3, May/June, pp.241247.

7. Beck, C., Kosnik, C. (2006). Innovations in Teacher Education. A Social Constructivist Approach. The USA: State University of New York Press.

8. Berry, A.,Loughran, J. (2000). Developing an Understanding of learning to Teach in Teacher Education. In Berry, A. and Loughran, J. (Eds.) Exploring Myths and Legends of Teacher Education. Proceedings of the third international conference on self-research of teacher education practices. Pp. 25-29. 
9. Bluma, D. (2012). Professionalism of Teacher Educators. In Nowosad, I. and Kobylecka, E. (Eds.) Teachers Training in the European Space of Higher Education. Poland: Wydawnictwo Adam Marszalek, No. 1(3), pp.110-129.

10. Borko, H., Liston, D., Whitcomb, J.A. (2007). Genres of Empirical Research in Teacher Education. Journal of Teacher Education, Vol.58, No.1, pp.3-11.

11. Boud, D. (2003). Enhancing Learning through Self-Assessment. London and New York: RoutledgeFalmer Taylor\&Francis Group.

12. Boud, D., Falchikov, N. (1989). Quanitative Studies of Student Self-assessment in Higher Education: A Critical Analysis of Findings. Higher Education, Vol. 18, No. 5, pp. 529549.

13. Bowen, T., Marks, J. (1994). Inside Teaching. Oxford: Heinemann.

14. Cartney, P. (2010). Exploring the use of peer assessment as a vehicle for closing the gap between feedback given and fedback used. Assessment and Evaluation in Higher Education. Vol.35, No.5, pp.551-564.

15. Cohen. L., Manion. L.,Morrison, K. (2007). Research Methods in Education. London and New York: Routledge Taylor\&Francis Group.

16. Coolahan, J. (2002). Teacher Education and the Teaching Career in an Era of Lifelong Learning. Paris: Organisation for Economic Co-operation and Development (OECD)

17. Crandall, J. (2000). Language Teacher Education. Annual Review of Applied Linguistics. USA: Cambridge University Press, pp. 34-55.

18. Creswell, J. W. (2009). Research design: Qualitative, Quantitative and Mixed Methods Approaches. USA: Sage Publications, Inc.

19. Darling-Hammond, L.,Sykes, G. (1999). Teaching as the Learning Profession: Handbook of policy and practice. San Francisco CA: Jossey Bass Publishers.

20. Dochy, F., Segers, M., Sluijsmans, D. (1999). The Use of Self-, Peer and Co-assessment in Higher Education: a review. Studies in Higher Education. Vol.24, No.3, pp.331-350.

21. Drew, S. (2001). Perceptions of what helps learn and develop in education. Teaching in Higher Education. Vol.6, No.3, pp.309-331.

22. Duval, T. S., Wicklund, R. A. (1972). A theory of objective self-awareness. New York: Academic Press.

23. Falchikov, N., Goldfinch, J. (2000). Student Peer assessment in Higher Education: A Meta-Analysis Comparing Peer and Teacher Marks. Review of Educational Research. Vol.70, No.3, pp.287-322.

24. Geske, A., Grīnfelds, A. (2001). Izglìtības pētījumu metodologija un metodes. R.: RaKa.

25. Green, K. (2006). No Novice Teacher Left Behind: Guiding Novice Teachers to Improve Decision-Making Through Structured Questioning. Penn GSP Perspectives on Urban Education, Volume 4, Issue 1, pp 1-9 http://www.urbanedjournal.org (22.11.2013).

26. Hahele, R. (2006). Pašnovērtējums mācību procesā. Rīga: RaKa.

27. Huber, G.L., Gürtler, L. (2013). AQUAD 7. Manual: The Analysis of Qualitative Data. Germany: Softwarevertrieb Günter Huber.

28. (2007). Improving the Quality of Teacher Education. Communication from the Commission to the Council and the European Parliament. Brussels: Commission of the European Communities.

29. Jokinen, H., Saranen, E. (1998). Development of Student Teachers' Self-Assessment. In Jokinen, H. and Rushton, J. (Eds.) Changing Contexts of School Development - The Challenges to Evaluation and Assessment. http://ktl.jyu.fi/arkisto/verkkojulkaisuja/ electronic/001/jokinen.htm (27.11.2013).

30. Klenowski, V. (1995). Student Self-Evaluation Processes in Student-centred Teaching and Learning Contexts of Australia and England. Assessment in Education: Principles, Policy\&Practice. Vol. 2, No. 2, pp. 145-163. 
31. Knowles, M. S. (1975). Self-directed Learning. A guide for Learners and Teachers. New York: Association Press.

32. Koḳe, T. (2002). Mūžizglītības pedagoğiskie pamati. Skolotājs. Nr.2, 4.-8.lpp.

33. Koshy, V. (2005). Action Research for Improving Practice. Great Britain: SAGE Publications.

34. Kroplijs, A., Raščevska, M. (2010). Kvalitatīvās pētniecības metodes sociālajās zinātnēs. 2. izdevums. Rīga: RaKa.

35. Lasmanis, A. (2002). Datu ieguves, apstrādes un analīzes metodes pedagogijas un psihologijas pētījumos. R.: SIA Izglītības soḷi.

36. Lee, H-J. (2005). Understanding and Assessing Pre-service Teachers' Reflective Thinking. Teaching and Teacher Education, 21, pp. 699-715.

37. Lieǵeniece, D. (2002). Ievads andragogijā. R.: RaKa.

38. Loughran, J. (2006). Developing Pedgogy of Teacher Education: Understanding teaching and learning about teaching. The USA and Canada: Routledge Taylor\&Francis Group.

39. McAlpine, M. (2002). Principles of Assessment. CAA Centre, University of Luton.

40. Moore, A. (2004). The Good Teacher. Dominant Discourses in Teaching and Teacher Education. London and NewYork: RoutledgeFalmer Taylor\&Francis Group.

41. Mundhenk, L. G. (2004). Toward an Understanding of What it Means to be Student Centered: A New Teacher's Journey. Journal of Management Education 28, pp 447-462.

42. Povinelli, D. J., \& Prince, C. G. (1998). When self met other. In M. Ferrari \& R. J. Sternberg (Eds.), Self-awareness: Its nature and development New York: Guilford; pp. 37-107.

43. Rogers, C. (1969). Freedom to Learn. New Yourk: Merill.

44. Sedikides, C., Strube, M. J. (1997). Self-evaluation: To thine own self be good, to thine own self be sure, to thine own self be true, and to thine own self be better. Advances in Experimental Social Psychology. Vol. 29, pp. 206-269.

45. Silvia, P. J.,Phillips, A. G. (2004). Self-Awareness, Self-Evaluation, and Creativity. Personality and Social psychology Bulletin, Vol.30, No.8, pp. 1009-1017.

46. Sluijsmans, D., Dochy F., Moerkerke G. (1999). Creating a Learning Environment by Using Self-, Peer- and Co-assessment. Learning Environment Research, pp. 293-319. Kluwer Academic Publishers.

47. Sparks-Langer, G., Colton, A. (1991). Synthesis of research on teaching reflective thinking. Educational Leadership, 48(6), pp. 37-44.

48. Struyven, K., Dochy, F., Janssens, S. (2005). Students' perceptions about evaluation and assessment in higher education: a review. Assessment and Evaluation in Higher Education. Vol. 30, No. 4, pp. 331-347.

49. Špona, A. (2006). Audzināšanas process teorijā un praksē. Rīga: RaKa.

50. Taras, M. (2002). Using Assessment for Learning and leraning from Assessment. Assessment and Evaluation in Higher Education. Vol.27, No.6, pp.501-510.

51. VISC (2009). Skolēnu mācību sasniegumu vērtēšana vidusskolā. Metodiskais materiāls. Rìga: Valsts izglìtības satura centrs.

52. Vygotsky, L. (1978). Interaction between learning and development. Readings on the Development of Children. Gauvain, M. And Cole, M. (Eds.) (1997); pp.29-36.

53. Žogla, I. (2001). Didaktiskie modelıi augstskolā. Skolotājs. Nr.6, 19.-26.lpp.

Mg. ed. sc.

Evija Latkovska

Dr. psych., prof.

Lūcija Rutka
University of Latvia, Faculty of Education, Psychology and Art, Department of Pedagogy; evija.latkovska@lu.lv

University of Latvia, Faculty of Education, Psychology and Art, Department of Pedagogy; lucija.rutka@lu.lv 